\title{
Effect Of Innovation On Performance Of County Governments In Kenya
}

\author{
Wahinya Grace Njeri \\ Jomo Kenyatta University of Agriculture and Technology (JKUAT), \\ Nairobi Kenya \\ Prof. Mukulu Elegwa \\ Jomo Kenyatta University of Agriculture and Technology (JKUAT), \\ Nairobi Kenya \\ Prof. Waititu Anthony \\ Jomo Kenyatta University of Agriculture and Technology (JKUAT), \\ Nairobi Kenya
}

\begin{abstract}
The purpose of this study was to determine the effect of planning on performance of county governments in Kenya. Questionnaire was used to collect data from seven counties in Kenya drawn from 47 county governments in Kenya. Two tools of analysis were adopted by this study namely: correlation analysis and regression analysis. The correlation analysis was used to show the positive correlation between the predictor and response variables while regression analysis was used to explain the relationship between the predictor and response variables. R-squared was used to provide the strength of the relationship between the model and the response variable and determine its goodness fit. While $F$ statistics was used to test the significance of the regression model. The study adopted correlational research design. The findings revealed that performance of county government is significantly influenced by innovation. From the findings, the study concludes that the county governments should enhance on further improvement in the area of planning in order to enhance the benefit of planning on performance of county governance.
\end{abstract}

Key Words: Innovation, Performance, County Governments

\section{INTRODUCTION}

Strategic management provides overall direction that involves formulation and implementation of the organizational goals. This involves specifying the organizational objectives and from them, develops plans and policies to enable the organization achieve its set objectives as well as allocate resources to implement the plans. This is done through the consideration of resources and assessment of internal and external environments in which the organizations functions. Strategic management incorporates all management hitches that may arise soon the strategic plans are developed, when other management process functions must be performed. Strategic management vividly states that a plan is incomplete by the time it has been implemented and evaluated and hence managers in strategic management are called to consider daily operations in the context of a longer period as well as change of external environment. In order to support new initiatives that spring from certain changes in the organizational environment, organizational structure and other fundamentals of management have to be adequate (24). 
Planning refers to the act of developing broad plans of action necessary to attain the organization's goals as well as objectives, establishing and periodically confirming the organization's mission and its context for management. This means, allocating resources on a basis consistent with strategic directions and goals and objectives, and managing the various lines of business and deploying the organization mission and strategy that is, articulating and communicating it, as well as developing action plans at lower levels that are supportive of those at the enterprise level (19).

Planning is a core variable as it gives organizations the direction they should take, what they wish to do in totality, where they are and where they wish to go. Strategic planning is the procedure of developing tactics, strategies, and organization objectives to achieve the mission of the organization. The organization produces short and long-term objectives by means of the mission statement. Objectives in the case of public sector may include, revenue collection goals and customer as well as citizen satisfaction reckonings. The next step in planning is developing strategies to help the organization in the accomplishment of the objectives. For instance, better training and monitoring of feedback scores are strategies that held in achievement of higher customer satisfaction. This is followed by development of actionable steps or tactics. A tactic tied to the customer satisfaction goal and the training strategy is hiring an external training consultant for a chain of service training sessions (25).

\section{STATEMENT OF THE PROBLEM}

Strategic Management Practices: Planning, Governance, Quality Management and Innovation are central organization performance. Innovation ensures that individual county government strives to ensure competitive edge. It ensures application of technology, protection, identification, selection and value creation (26). County governments are vital vehicles for grassroots social-economic development in Kenya. Strategic management practices are therefore, important to county government's prudent management of resources for optimal performance. However, county governments face a number of challenges in executing their constitutional mandated functions. These challenges are as a result of poor strategic management practices. Studies by Ondigi (21), Korir (10) and Muli (16) indicate that poor planning in county governments has resulted to high levels of corruption. Planning within the county government in Kenya is wanting as envisioned by poor performance. It is, therefore, important that the County Government should improve their planning to enhance their performance. The challenges faced by the county governments as evidenced by the research can be attributed to poor implementation of planning. This study sought to establish the effects of planning on the performance of county government in Kenya and thus fill the knowledge gap.

\section{RESEARCH QUESTION}

The study sought to answer a key question:

To what extent does innovation affect the performance of county governments in Kenya?

\section{LITERATURE REVIEW}

This study focused on General Theory of Innovation (GTI). This theory was innovated by Greg (9). His aim was to create a theory concerned with supporting machineries for emergence, survival and end of the artificial systems.GTI brings out the link between various organizations applications, which address the needs of real projects. General Theory of Innovation states that innovation in the area of strategic management is the identification of a transformation required for getting something in the right position in an organization with the determination of attaining economical advantage. This implies that innovation is massively more important in strategic management than in any other area of institutional activities such as product or 
process innovation. Application of GTI to the strategic management supported creation of specialized tools such as Value Matrix, Generic Growth Strategies and Value Growth Templates (3).

Literature review on General Theory of innovation revealed that, though the theory has been developed for many years, it still has its own critics owing to the fact that there is no such a thing as perfect theory. To overcome this limitation of non-perfection, continuous improvement on the theory should be ensured. The theory should receive further improvement and evolution. The other limitation of the GTI theory is lack of enough skilled personnel to guide on the GTI theory operation. This may be overcome by continuous training of the personnel involved in the operation of the GTI theory (3). General Theory of Innovation is relevant to this study because it will help in anticipating new markets and the knowledge to apply in finding new sources of revenue, finding new markets for products and services, creating new powerful strategies and generating and controlling growth in order for the county governments to have significant advantage on the application of their strategic plans. Consequently, the General Theory of Innovation hypothesizes a positive relationship between innovation and performance.

Performance in the public sector has some general features which are accomplished in a performance measurement system that involves a relationship between inputs, process, outputs and outcomes which are then guided by two objectives that answers two questions: are we doing things right and are we doing the right things. The performance measurement system allows implementing some important actions and making some decisions based on quantifying the efficiency and effectiveness of past actions using appropriate information structure (18). Performance is no longer measured only on key performance indicators (KPI) such as return on investment (ROI), revenue, overhead and operational costs in modern years, but considered to involve not only financial considerations but also other factors including employee morale and productivity, social responsibility and reputation and innovation (2).

\section{CONCEPTUAL FRAMEWORK}

Innovation is an action which leads to a first-hand generating function or a new product (Mc Daniel, 2000). Pearce and Robinson (2010) outlines innovation as an impressive strategy that seeks to obtain the exceptional margins connected with the conception and customer reception of a new product or service. The notion of innovation is defined as a new arrangement or management process, a new plan, a new policy, a program or a new product or service produced in an organization (12). Bessant and Tidd (1) defines the innovation as marketing a developed or new product or as technical, design, production, management and viable practices in the use of a developed or new process or equipment for the first time. An organization is challenged by innovation to look beyond its well-known organizational restrictions and intellectual models and to contribute in an unbiased, inspired consideration of the empire of opportunities and often involves varying or transforming organization models, the outline on how the organization is going to make money, to make an organization more competitive (14). The key concept behind the perception of innovation systems is that innovation is a collaborative process (13).

According to Porter (23), strategy is the existence of a set of actions that will empower the organization to distinguish itself from its competitors and to uphold its viable position. Lendel and Varmus (11) outlines that the results of research have shown that organizations applying innovation are more successful compared with the organizations that do not apply innovation. Innovation is a leader that makes organizations contemplate on why they renovate before endeavoring to make an innovation. Innovation empowers top management to follow the 
activities of their counter parts, to reach customer market information, to use organization resources efficiently and to make effective funds in research and development (20). These activities have been found to confidently impact organization performance (28). Managers will strategize and allocate resources appropriately to improve firm innovation performance under the environmental conditions of an increasingly competitive environment and constantly changing customer needs. The presentation of innovation in an organization can ensure the execution of successful innovations by lessening acute interior and exterior eventualities (5).

Arising from the literature review, the following represents the conceptualization of the study.

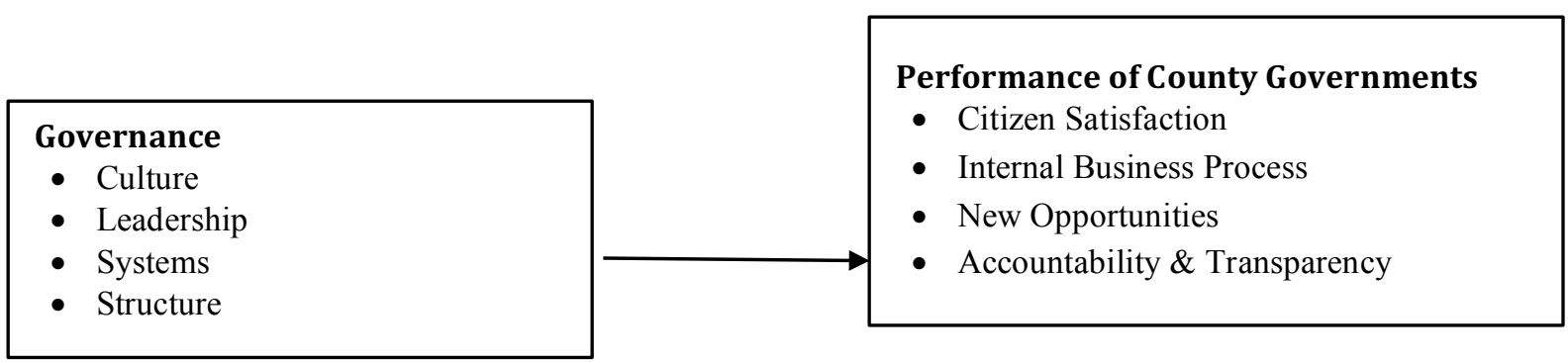

\section{Independent Variable}

\section{Figure 1: Conceptual Framework}

\section{Dependent Variable}

\section{RESEARCH METHODOLOGY}

To test the effect of innovation on performance of county governments, this study adopted correlational research design. Data was collected once over a period of one month from a sample of seven counties in Kenya to represent Kenya as a region. The correlation analysis was used to show the positive correlation between the predictor and response variables while regression analysis was used to explain the relationship between the predictor and response variables. R-squared was used to provide the strength of the relationship between the model and the response variable and determine its goodness fit. While F statistics was used to test the significance of the regression model.

\section{MEASUREMENT OF VARIABLES}

This study variables were measured using continuous indicators. Innovation was measured by nine items namely: Innovation culture is well developed in county, county handles innovation obstacles well, county has embraced internet in communication and exchange of data and information, county ensures new technology machines and equipment are serviceable, innovation portfolio process is effective in managing innovation risk, county innovation process is synchronized with strategy, use of IT enable coordination and integration of activities, county uses different communication devices in operations, county government use technology to improve value addition. A five point likert scale ranging from one (Strongly agree) to five (Strongly disagree) was used. This measure has been adopted from previous research of (27). The Cronbach's alpha coefficient value was 0.91 and this is an indication that the internal reliability of the used scale was quite satisfactory. According to Cronbach, (4), for normal research, reliability that is as low as 0.7 is basically acceptable. The results, based on coefficient value indicates that the data has high level of internal consistency. Several parameters were used to measure county government performance. They include: new opportunities benefit all stakeholders, county arrangements ensure inclusion and fairness, county cake is shared among all county residents, employee satisfaction via involvement and empowerment, lead to efficiency in internal processes, efficient public procurement practices are pursued to ensure sound management of expenditure, county relates well with all stakeholders, good communication process ensure internal processes run smoothly, suppliers are satisfied with quality and level of information in contracts and county emphasizes 
assessment of citizens needs and expectations. A five point likert scale ranging from one (Strongly agree) to five (Strongly disagree) was used. The Cronbach's alpha coefficient value for performance was 0.78 and this indicate that the internal reliability of the scale was satisfactory.

\section{Descriptive Analysis for Governance}

\section{RESEARCH FINDINGS AND DISCUSSIONS}

Innovation was measured by Technology, Protection, Value Creation and Identification. The respondents were asked to indicate whether county governments use technology to improve value addition and $66.4 \%$ of the respondents agreed that county governments use technology while $33.6 \%$ disagreed on the use of technology to improve value addition in the counties. The study further sought to establish whether counties' use of IT enable coordination and integration of activities and $62.5 \%$ of the respondents agreed while $37.5 \%$ disagreed. The study further sought establish whether counties embrace internet in communication and exchange of data and information and $50.8 \%$ of the respondents indicated that counties for sure embrace internet in communication while $48.2 \%$ disagreed. Further $49.2 \%$ of the respondents indicated that counties ensures new technology machines and equipment are serviceable while $50.8 \%$ reported that counties do not. The study results show that most counties embrace technology and protection in their operations. However, this should be improved. Further, the study sought to establish whether county uses different communication devices in operations where $76.6 \%$ of the respondents agreed while $23.3 \%$ disagreed. $44.6 \%$ indicated that county innovation process is synchronized with strategy while $55.4 \%$ disagreed. Asked on whether portfolio process is effective in managing innovation risk, $43.7 \%$ agreed while $56.3 \%$ disagreed. To respond to whether innovation culture is welldeveloped in county, 31.2\% agreed while 68.8\% disagreed and further asked whether county handles innovation obstacles well, 32\% agreed while 68\% disagreed. The results indicate that, for innovation to be effective, county governments should improve on value creation and identification.

Table 1: Descriptive Statistics for Innovation

\begin{tabular}{|c|c|c|c|c|c|c|c|c|c|}
\hline & \multirow{2}{*}{$\begin{array}{c}\text { St.D } \\
\%\end{array}$} & \multirow{2}{*}{$\begin{array}{c}\text { Sl.D } \\
\%\end{array}$} & \multirow{2}{*}{$\begin{array}{l}\mathrm{D} \\
\%\end{array}$} & \multirow{2}{*}{$\begin{array}{l}\mathrm{A} \\
\% \\
\end{array}$} & \multirow{2}{*}{$\begin{array}{c}\text { St.A } \\
\%\end{array}$} & \multicolumn{4}{|c|}{ Summary } \\
\hline & & & & & & $\mathrm{Mn}$ & $\mathrm{Md}$ & Mo & S.D \\
\hline $\begin{array}{l}\text { County government use technology to } \\
\text { improve value addition }\end{array}$ & $1.6 \%$ & $5.5 \%$ & $26.6 \%$ & $57.8 \%$ & $8.6 \%$ & 4 & 4 & 4 & 1 \\
\hline $\begin{array}{l}\text { Use of IT enable coordination and } \\
\text { integration of activities }\end{array}$ & $1.6 \%$ & $9.4 \%$ & $26.6 \%$ & $50.8 \%$ & $11.7 \%$ & 4 & 4 & 4 & 1 \\
\hline $\begin{array}{l}\text { County has embraced internet in } \\
\text { communication and exchange of data and } \\
\text { information }\end{array}$ & $3.1 \%$ & $28.9 \%$ & $17.2 \%$ & $37.5 \%$ & $13.3 \%$ & 3 & 4 & 4 & 1 \\
\hline $\begin{array}{l}\text { County ensures new technology machines } \\
\text { and equipment are serviceable }\end{array}$ & $3.1 \%$ & $23.4 \%$ & $24.2 \%$ & $38.3 \%$ & $10.9 \%$ & 3 & 3 & 4 & 1 \\
\hline $\begin{array}{l}\text { County uses different communication } \\
\text { devices in operations }\end{array}$ & $0.0 \%$ & $11.7 \%$ & $11.7 \%$ & $66.4 \%$ & $10.2 \%$ & 4 & 4 & 4 & 1 \\
\hline $\begin{array}{l}\text { County innovation process is synchronized } \\
\text { with strategy }\end{array}$ & $3.1 \%$ & $26.6 \%$ & $25.8 \%$ & $43.8 \%$ & $0.8 \%$ & 3 & 3 & 4 & 1 \\
\hline $\begin{array}{l}\text { Innovation portfolio process is effective in } \\
\text { managing innovation risk }\end{array}$ & $3.9 \%$ & $22.7 \%$ & $29.7 \%$ & $40.6 \%$ & $3.1 \%$ & 3 & 3 & 4 & 1 \\
\hline $\begin{array}{l}\text { Innovation culture is well developed in } \\
\text { county }\end{array}$ & $3.9 \%$ & $35.9 \%$ & $28.9 \%$ & $28.1 \%$ & $3.1 \%$ & 3 & 3 & 2 & 1 \\
\hline County handles innovation obstacles well & $3.9 \%$ & $32.0 \%$ & $32.0 \%$ & $28.9 \%$ & $3.1 \%$ & 3 & 3 & 2 & 1 \\
\hline
\end{tabular}

Several factors were used to measure performance of County Governments in the study. The study findings showed that $81.2 \%$ of the respondents reported that their counties emphasized on assessment of citizen needs and expectations, whereas $18.8 \%$ reported that counties did not have any emphasize on assessment of citizen needs and expectations. This is an indication 
that needs and expectations of citizens in most counties were considered and met. Second, $51.6 \%$ of the respondents reported that the County cake is shared among all county residents, while $48.4 \%$ reported that the county cake is not shared among all county residents. The findings are an indication that the county government management should improve on sharing of county cake among citizens in their respective counties. Sixty Five point Seven percent $(65.7 \%)$ reported that employee satisfaction, via involvement and empowerment lead to efficiency in internal processes as while $34.3 \%$ of the respondents disagreed with the statement. These results show that employees in most counties were involved and empowered in running of the county governments. When asked whether good communication process ensure internal processes run smoothly, $75 \%$ of the respondents agreed with the statement while $25 \%$ of the respondents disagreed with the statement a prove that good communication resulted to improved performance. Further, the respondents were asked if county arrangements ensured inclusion and fairness, $53.9 \%$ of the respondents reported that the arrangements included stakeholders and were fair while $46.3 \%$ reported non-inclusion and unfair. These results posed a platform where the county governments should improve on inclusion and fairness in their operation management to improve on performance of county governments.

When asked if county governments pursued efficient public procurement practices to ensure sound management of expenditure, majority of the respondents $(65.7 \%)$ agreed to the statement while $34.3 \%$ disagreed with the statement. The results show that most counties applied effective public procurement practices that ensured sound management of expenditure and this led to improvement in performance. The researcher further asked the respondents whether the suppliers are satisfied with quality and level of information in county government contracts and $55.5 \%$ reported that they were while $44.5 \%$ disagreed with the statement. The results communicate that county governments should consider improving the quality and level of information in county government contracts.

Table 2: Descriptive analysis for County Government Performance

\begin{tabular}{|c|c|c|c|c|c|c|c|c|c|}
\hline & \multirow{2}{*}{$\begin{array}{l}\text { St.D } \\
\%\end{array}$} & \multirow{2}{*}{$\begin{array}{c}\text { Sl.D } \\
\%\end{array}$} & \multirow{2}{*}{$\begin{array}{l}\mathrm{D} \\
\%\end{array}$} & \multirow{2}{*}{$\begin{array}{l}\mathrm{A} \\
\%\end{array}$} & \multirow{2}{*}{$\begin{array}{l}\text { St.A } \\
\%\end{array}$} & \multicolumn{4}{|c|}{ Summary } \\
\hline & & & & & & $\mathrm{Mn}$ & Md & Mo & S.D \\
\hline $\begin{array}{l}\text { County emphasizes assessment of citizen } \\
\text { needs and expectations }\end{array}$ & $0.0 \%$ & $7.8 \%$ & $10.9 \%$ & $78.1 \%$ & $3.1 \%$ & 4 & 4 & 4 & 1 \\
\hline $\begin{array}{l}\text { County cake is shared among all county } \\
\text { residents }\end{array}$ & $6.2 \%$ & $23.4 \%$ & $18.8 \%$ & $47.7 \%$ & $3.9 \%$ & 3 & 4 & 4 & 1 \\
\hline $\begin{array}{l}\text { Employee satisfaction, via involvement and } \\
\text { empowerment, lead to efficiency in internal } \\
\text { processes }\end{array}$ & $0.8 \%$ & $22.7 \%$ & $10.9 \%$ & $64.1 \%$ & $1.6 \%$ & 3 & 4 & 4 & 1 \\
\hline $\begin{array}{l}\text { Good communication process ensure } \\
\text { internal processes run smoothly }\end{array}$ & $0.0 \%$ & $11.7 \%$ & $13.3 \%$ & $67.2 \%$ & $7.8 \%$ & 4 & 4 & 4 & 1 \\
\hline New opportunities benefit all stakeholders & $4.7 \%$ & $26.6 \%$ & $25.0 \%$ & $42.2 \%$ & $1.6 \%$ & 3 & 3 & 4 & 1 \\
\hline $\begin{array}{l}\text { County arrangements ensure inclusion and } \\
\text { fairness }\end{array}$ & $5.5 \%$ & $19.5 \%$ & $21.1 \%$ & $51.6 \%$ & $2.3 \%$ & 3 & 4 & 4 & 1 \\
\hline $\begin{array}{l}\text { Efficient public procurement practices are } \\
\text { pursued to ensure sound management of } \\
\text { expenditure }\end{array}$ & $2.3 \%$ & $10.2 \%$ & $21.9 \%$ & $64.1 \%$ & $1.6 \%$ & 4 & 4 & 4 & 1 \\
\hline $\begin{array}{l}\text { Suppliers are satisfied with quality and } \\
\text { level of information in contracts }\end{array}$ & $0.8 \%$ & $20.3 \%$ & $23.4 \%$ & $53.9 \%$ & $1.6 \%$ & 3 & 4 & 4 & 1 \\
\hline County relates well with all stakeholders & $0.0 \%$ & $21.1 \%$ & $31.2 \%$ & $43.8 \%$ & $3.9 \%$ & 3 & 3 & 4 & 1 \\
\hline
\end{tabular}




\section{Correlation Analysis}

Performance had a positive and significant correlation with planning $(\mathrm{r}=0.606$, $\mathrm{p}$-value $<$ 0.000). This means, an increase in innovation leads to an increase in county government performance.

Table 3: Correlations Analysis

\begin{tabular}{lccc}
\hline & $\mathrm{X}$ & $\mathrm{Y}$ \\
\hline Planning & Correlation & 1 & $606^{* *}$ \\
& Sig. (2-tailed) & & 0.000 \\
$\mathrm{~N}$ & 1 & 128 \\
\hline
\end{tabular}

**. Correlation is significant at the 0.01 level (2-tailed).

*. Correlation is significant at the 0.05 level (2-tailed).

Key: Y=County Government Performance

$\mathrm{X}=$ Innovation

\section{Regression Analysis}

Ho1: There is no significant relationship between Innovation and the Performance of County Governments in Kenya

\section{Innovation and County government performance Model Summary}

The coefficient of determination ( $\mathrm{R}$ squared) of 0.367 indicates that $36.7 \%$ of county government performance can be explained by innovation. The adjusted $\mathrm{R}$ square of $36.2 \%$ explains that innovation in the exclusion of the constant variable explain there is no change in county government performance. The remaining percentage can be explained by other factors not included in the model. The $\mathrm{R}$ indicates the correlation coefficient of the effects of innovation, an $\mathrm{R}=0.606$ shows that there is a positive relationship between innovation and county government performance. The standard error of estimate (0.42) shows the average deviation of the independent variables from the line of goodness fit.

Table 4: Innovation and County government performance Model Summary

\begin{tabular}{|c|c|c|c|c|}
\hline Model & $\mathrm{R}$ & R Square & Adjusted R Square & $\begin{array}{l}\text { Std. Error of the } \\
\text { Estimate }\end{array}$ \\
\hline $\begin{array}{l}1 \\
\text { a Predi }\end{array}$ & $\begin{array}{l}0.606^{\mathrm{a}} \\
\mathrm{nt}), \mathrm{Inn}\end{array}$ & 0.367 & 0.362 & 0.42323 \\
\hline
\end{tabular}

\section{Innovation and County Government Performance}

The $F$ statistics was used to test for the model goodness of fit. Table 5 ( $F=73.030$, $p$ value $=0.00$ ) indicates that there is a significant relationship between innovation and county government performance and at least the slope ( $ß$ coefficient) is not zero.

Table 5: Innovation and County Government Performance ANOVA ${ }^{a}$

\begin{tabular}{lrrrrr}
\hline Model & Sum of Squares & df & Mean Square & F & Sig. \\
\hline Regression & 13.081 & 1 & 13.081 & 73.030 & $.000^{\mathrm{b}}$ \\
Residual & 22.570 & 126 & .179 & & \\
Total & 35.651 & 127 & & & \\
\hline
\end{tabular}

a. Dependent Variable: PERFORMANCE

b. Predictors: (Constant), INNOVATION

\section{Innovation and County Government Performance Regression Weights}

The study hypothesized that innovation does not affect the performance of county governments in Kenya. The study findings showed that there was a positive and significant relationship between innovation and county government performance $((\beta=0.452, p$ value $=0.000<0.05$ ). This means that a unit increase in innovation leads to an increase in county 
government performance by 0.452 . Since the $\mathrm{p}$ value was less than 0.05 , the null hypothesis was rejected and the alternative hypothesis was accepted. The study therefore concluded that innovation has a significant influence on performance of county governments in Kenya.

Table 6: Innovation and County Government Performance Regression Weights

\begin{tabular}{lccccc}
\hline Model & \multicolumn{2}{c}{ Unstandardized Coefficients } & Standardized Coefficients & $\mathrm{t}$ & Sig. \\
& $\mathrm{B}$ & Std. Error & Beta & & \\
\hline (Constant) & 1.908 & .179 & & & 10.658 \\
INNOVATION & .452 & .053 & .006 & 8.546 & .000 \\
\hline
\end{tabular}

a. Dependent Variable: PERFORMANCE

\section{DISCUSSION}

The findings of the study greatly contradicts the hypothesis that innovation does not affect the performance of county governments in Kenya. The results of the regression analysis indicates that innovation has significant effect on performance of county governments in Kenya. Innovation was first compared to other variables and this is an implication that good performance by county governments is highly influenced by innovation. Similar conclusions were drawn by Eleanor (8), Walker, Damanpour and Devece (29) and Mwangi (17).

\section{SUMMARY AND CONCLUSION}

The objective of this paper was to investigate the effect of innovation on the performance of county governments in Kenya. It was established that through innovation, The study revealed that counties are handling innovation obstacles through the integrated systems like IFMIS and IFMIS e-procurement system which are enhancing efficiency in planning, budgeting, procurement, expenditure management and reporting in both levels of National and county governments in Kenya. As such, innovation was concerned with technology where the use of technology to improve value addition enables coordination and integration of activities and allows the users to embrace internet in communication and exchange of data and information that eventually leads to great positive effect on the performance of county governments in Kenya. Based on the results of this study, it is concluded that innovation as used by county governments is positive significant factor in relation to county government performance.

\section{RECOMMENDATIONS}

From the findings of the study, it is recommended that the county government managers should enhance further improvement to harness the benefit of innovation on performance of county governments. While the objective of the study was successfully met, it is recommended that future research on innovation may be conducted in other state bureaucracies that have better policies and practices than county governments.

\section{References}

Bessant, J., \& Tidd, J. (2007). Innovation and Entrepreneurship. Chichester UK: Wiley.

Chenhall, R. H., \&Langfield, K. (2007). Multiple perspectives of performance measures. European Management Journal, 25(4), 266-282.

Clayton, M. C., \&Raynor,M. E. (2003). The Innovator's Solution. Boston: HBS Press.

Cronbach, L. J. (2004). My current thoughts on coefficient alpha and successor procedures. Educational and Psychological Measurement Journal, 64(1), 391-418.

Donaldson, L. (2001). The contingency theory of organizations. Thousand Oaks, CA: Sage Publications.

Dwivedi, M. W. (2015). The unified theory of acceptance and use of technology (UTAUT). Journal of Enterprise Information Management, 28(3), 443-488.

Eleanor, G. (2014). Studying the impact of Innovation on Organizations, Organizational Populations and Organizational Communities. The Public Sector Innovation Journal,19(3), 2-14. 
Greg Y. F. (1988). Evolutionary patterns of transition from a system to the super system in TRIZ. Journal in Management, 1(19)90, 26-90.

Korir, V. C. (2013). Challenges affecting devolution of Public Sector in Local Authorities in Kenya, a Case of County Government of Kericho, Unpublished MBA project, Kenyatta University, Nairobi, Kenya.

Lendel, V., \& Varmus, M. (2011). Creation and implementation of the innovation strategy in the enterprise. Economics and Management, 16(1), 819-826.

Lopez-Nicolas, C., \&Merono-Cerdan, A. L. (2011). Strategic knowledge management, innovation and performance. International Journal of Information Management, 31(6), 502-509.

Lundvall, B. (2007). National innovation Systems Analytical concept and development tool. Industry \& Innovation, $14(1), 95-119$.

Mang, P. (2000).Strategic Innovation: Constantinos Markides on Strategy and Management. The Academy of Management Review, 14 (3), 43-45.

Mc Daniel, B.A. (2002). Entrepreneurship and innovation: An economic approach. London: M.E Sharp.

Muli, J. N. (2014). The Challenges of Implementation of Devolution Strategy at the Nairobi County Government in Kenya. Unpublished MBA project, University of Nairobi, Kenya.

Mwangi, P. K. (2016). Influence of Strategy Implementation on the Performance of Manufacturing Small and Medium Firms in Kenya. Unpublished PhD Thesis. Jomo Kenyatta University of Technology, Kenya.

Neely, A., Adams C., \&Kennerly, M. (2007). The Performance Prism. The Scorecard for Measuring and Managing Business Success. Glouster, UK: Financial Times, Prentice Hall

Nickols F. (2016). Strategy, Strategic Management, Strategic Planning and Strategic Thinking. Management Journal, 1(1), 4-7.

Oke, A., Walumbwa, F. O., \& Myers, A. (2012). Innovation strategy, human resource policy, and firms' revenue growth: The roles of environmental uncertainty and innovation performance. Decision Sciences Journal, 43(2), $273-302$.

Ondigi C. N., (2014) Challenges Facing Devolution in Kenya: A Comparative Study. Nairobi, Kenya.

Pearce, J.A., \& Robinson, R.B. (2010). Strategic management, formulation, Implementation and control, (10th Ed). New York: McGraw-Hill Companies, Inc.

Porter, M., E. (2008). The Five Competitive Forces That Shape Strategy. HBR, Harvard Business Review. Retrieved on July 4, 2017 from http://www.temoa.info/node/2440.

Smith, R. J. (2005). Strategic Management and Planning in the Public Sector. London. Longman.

Thompson, J., \& Strickland, A.J. (2003). Strategic Management: Concepts and Cases. Homewood, IL: Irwin.

Thompson, A.A, \& Strickland, A.J. (2007). Strategic Management: Concepts and Cases. (12 ${ }^{\text {th }}$ Ed). New York: McGraw-Hill.

Tsang, K., K. (2012). The use of midpoint on Likert Scale: The implications for Educational Research. Hong Kong Teachers Centre Journal, 11(1), 121-130.

Verhees, F. J. H. M., \& Meulenberg, M. T. G. (2004). Market orientation, innovativeness, product innovation, and performance in small firms. Journal of Small Business Management, 42(2), 134-154.

Walker, R. M., Damanpour F., \& Devece C. A (2010). Management Innovation and Organizational Performance: The Mediating Effect of Performance Management. Journal of Public Administration Research and Theory, 21(1), 367386. 